\title{
KONTRIBUSI PENGAMATAN GEODESI MODERN DALAM MEMAHAMI DINAMIKA TEKTONIK DI INDONESIA: ESTIMASI KUTUB EULER LEMPENG MINOR SUNDA
}

\author{
DINA ANGGRENI SARSITO ${ }^{1}$, SUSILO $^{2}$, DHOTA PRADIPTA $^{1}$, HERI ANDREAS $^{1}$
}

1. Kelompok Keilmuan Geodesi - FITB - ITB, Jl. Ganesa 10 Bandung, Email: dsarsito@gd.itb.ac.id

2. Badan Informasi Geospasial, Jalan Raya Bogor km. 46, Cibinong.

\begin{abstract}
Sari - Penentuan Kutub Euler Sesaat Resen pada saat ini adalah salah satu kontribusi bidang geodetik untuk penentuan geo-kinematik bumi menggunakan asumsi geometrik bola ideal. Parameter kutub Euler diestimasi berdasarkan perubahan kecepatan/ pergerakan minimal tiga stasiun GNSS-GPS yang terletak di zona rigid yang sama. Dengan menggunakan best fitting L2-Norm dari data observasi GNSS GPS pada tahun 1992-2017, hasil estimasi yang dihasilkan memberikan sensitivitas yang tidak homogen terhadap pola distribusi titik pengamatan. Residu absolut dari pengamatan terhadap hasil estimasi kecepatan kutub Euler akan menunjukkan keberadaan stasiun di dalam atau di luar zona rigid. Dengan menerapkan semua langkah yang disebutkan, nilai estimasi Kutub Euler Sesaat Resen dari blok mikro Sunda adalah di bawah $5 \mathrm{~mm} /$ tahun untuk residu absolut dengan akurasi hingga $1 \mathrm{~mm} / \mathrm{tahun}$, dengan demikian parameter ini dapat digunakan sebagai informasi geo-kinematik yang akurat.
\end{abstract}

Kata kunci: Geodesi, Lempeng Minor, Sunda, Kutub Euler, L2-Norm Minimization

\begin{abstract}
Determination of Current Instantaneous Euler Poles is one of geodetic contribution for the geo-kinematic determination of the earth by using ideal spherical assumptions. The Euler pole parameters are estimated based on the shift or movement rate from al least three GNSS-GPS stations located in the same rigid zone. By applying best fitting L2-Norm from from 1992-2017 GNSS-GPS data observation, the estimation stability result given by the sensitivity of GNSS GPS station distribution pattern is not homogeneous but still in a range of rigid block accuracy. The absolute residuals of the observations from the Euler polar velocity estimation results indicate the presence of the stations within or outside the rigid zone. By applying all the mentioned steps, a stable estimation value of the Sunda micro-blocks Current Instantaneous Euler Poles of absolute residuals is estimated below $5 \mathrm{~mm} /$ year with accuracy up to $1 \mathrm{~mm} /$ year, and these parameters are used as geo-kinematic accurate information.
\end{abstract}

Keywords: Geodesi, Microblock, Sunda, Euler Pole, L2-Norm Minimization

\section{PENDAHULUAN}

Bermula dari Continental Drift Theory (Teori Apungan Benua) pada tahun 1912 oleh Alferd Wegener yang tidak menerangkan tentang penyebab pergerakan lempeng, disusul oleh kemajuan teknologi pemetaan dasar laut serta paleomagnetism bumi yang membuktikan secara kuantitatif pergerakan lempeng (plate), maka pada awal tahun 1960-an berkembang teori lanjutan yang menjelaskan penyebab/gaya penyebab pergerakan lempeng yaitu Plate Tectonic (Lempeng Tektonik). Suatu lempeng dapat terdiri atas kerak benua (continental crust), kerak samudera (oceanic crust) atau kombinasi keduanya, dimana batas antar lempengnya dapat berupa fenomena konvergen (tumbukan /collision), divergen (pemekaran/spreading) atau transform (sliding). Berdasarkan luas lempeng, diberikan beberapa klasifikasi umum dari yang berukuran luas sampai sempit, yaitu lempeng mayor, lempeng minor (blok) dan lempeng mikro (mikro-blok). Pergerakan lempeng ini bersifat dinamis sangat mempengaruhi perubahan morfologi dan tektonik bumi yang berdampak pada perubahan topografi serta batimetri permukaan bumi, baik dengan disertai fenomena gempabumi atau fenomena menggelincir tanpa disertai gempabumi (silent slip earthquake). Dengan demikian sangat diperlukan untuk mempelajari serta memahami fenomena pergerakan lempeng agar dapat mengestimasikan besarnya perubahan atau deformasi yang terjadi serta 
memperkirakan dampaknya.

Finite Rotation Pole (FRP) atau lebih dikenal sebagai Kutub Euler (KE) merupakan pengukuran parameter pergerakan relatif antar lempeng sebagai fungsi dari kecepatan rotasi dalam derajat/juta_tahun pada posisi horisontal geodetik (lintang, bujur) dari kutub suatu lempeng. Penentuan KE secara garis besar dapat dibagi menjadi 3 metode. Metode pertama adalah berdasarkan informasi geologi berupa fitting nilai anomali geomagnetik (isochrones) terhadap segmen zona rekahan dari punggungan tengah samudera (Turcotte \& Schubert, 2012). Metode kedua adalah menggunakan informasi geometrik geodetik pergeseran/kecepatan pergerakan dari titiktitik yang terletak di permukaan bumi yang terletak pada satu lempeng. Metode terakhir yang didasarkan pada hasil pengukuran teknologi satelit geodesi modern yaitu GNSS dan VLBI menghasilkan Current Instantaneous Euler Pole (Kutub Euler Sesaat
Resen/KESR). KESR selanjutnya digunakan untuk memprediksi gerakan deformasi sekular (linier) pada epoch mendatang dan untuk rekonstruksi posisi (Kutub Euler Rekonstruksi Total/ KERT) pada epoch lampau dari suatu lempeng sebagai efek pergerakan lempeng kaku (rigid-block). Cox \& Hart (1986) mengemukaan bahwa pada ekstrapolasi ke epok lampau dari KERT terdapat kemungkinan adanya Stages Euler Pole (SEP) yaitu KE yang mendefinisikan pergerakan lempeng hanya pada pada durasi terbatas (interval waktu tertentu) saja. Hal tersebut terjadi mengingat kecenderungan perubahan pola gerakan lempeng di daerah triple junction (pertemuan antar 3 lempeng) dimana setidaknya dua lempeng atau keseluruhan lempeng akan mengalami migrasi pergerakan berupa perubahan posisi kutub serta kecepatannya relatif terhadap waktu.

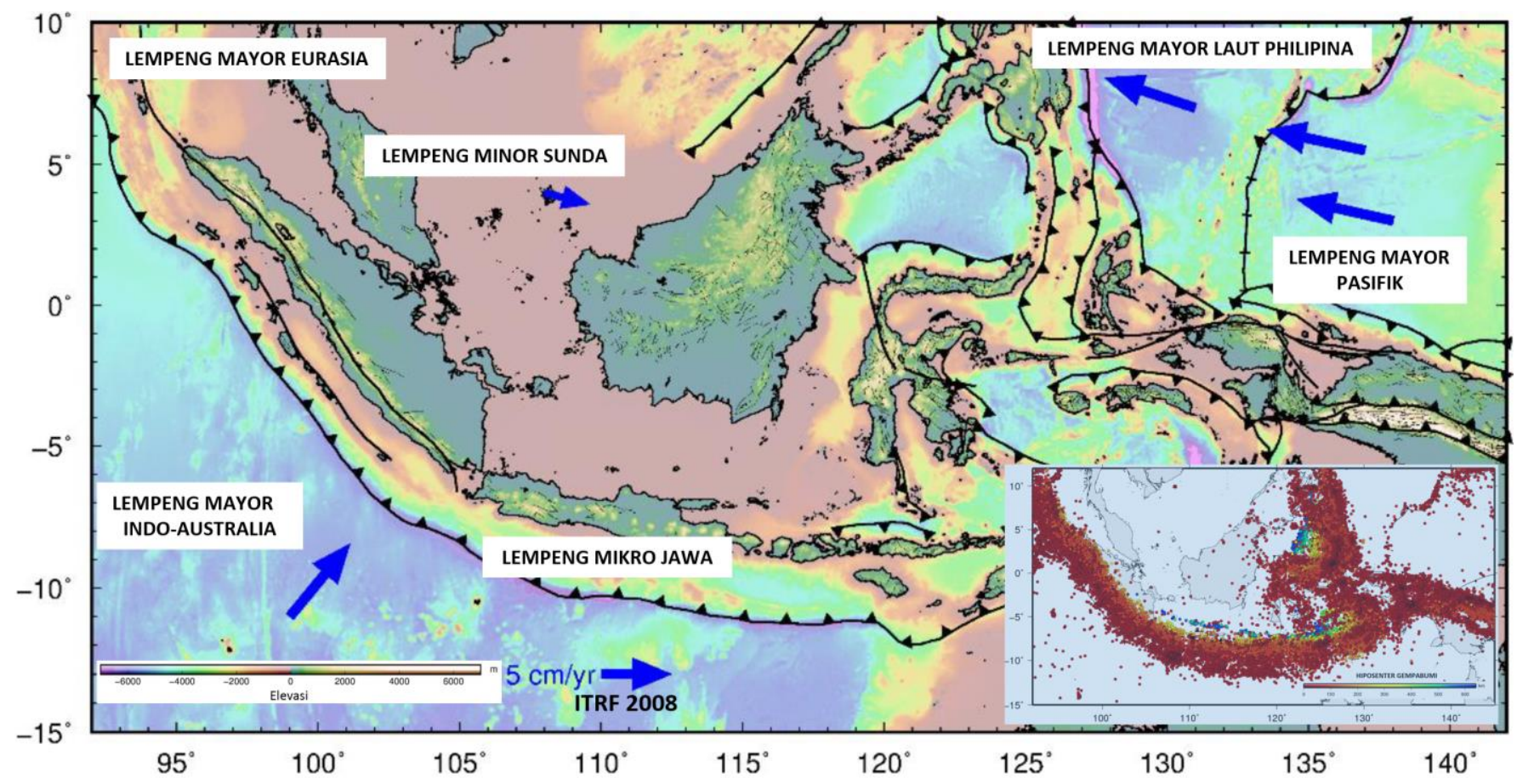

Gambar 1. Kondisi tektonik, kecepatan lempeng dalam ITRF2008 dan kegempaan (inset: sumber data katalog USGS dan NEIC) (modifikasi dari Hamilton (1979) dan Becker (2008)).

Indonesia (Gambar 1) merupakan wilayah tektonik yang luas yang membentang dari $93^{\circ}-142^{\circ}$ Bujur Timur sampai $7^{\circ}$ Lintang Utara $-14^{\circ}$ Lintang Selatan, merupakan 
pertemuan 4 lempeng mayor yaitu Lempeng Eurasia yang terletak di bagian Barat Laut yang relatif stabil dibandingkan dengan 3 lempeng lainnya yaitu Lempeng IndoAustralia yang terletak di bagian selatan dengan kecepatan pergerakan $7 \mathrm{~mm} /$ th ke arah Timur Laut dan Lempeng Laut Philipina Lempeng Pasifik dengan kecepatan pergerakan $11 \mathrm{~mm} /$ th ke arah utara-barat. Di zona ujung selatan dari lempeng mayor Eurasia, dalam satu dekade ini terdeteksi telah menjadi lempeng mikro Sunda (Sunda Block) dengan kecepatan pergerakan yang hampir serupa (Sella (2002), Kreemer (2003, 2006, 2014), Bock (2003), Prawirodirdjo (2004), Simons (2007), DeMets (2010), Argus (2011), Altamimi (2012), Mustafar (2017), Yong (2017), Susilo (2018)). Kuantifikasi parameter KESR dari para peneliti terdahulu dilakukan menggunakan data geologi atau data pengamatan geodetik GNSS. Pola sebaran stasiun pengamatan GNSS yang bervariatif serta durasi waktu pengamatannya menjadi penentuan tingkat keakurasian KESR. Untuk mengetahui secara lebih detil tentang parameter KESR lempeng minor Sunda maka di dalam penelitian ini digunakan semua data GNSS tipe kontinu dan tipe episodik dari Badan Informasi Geospasial Indonesia dengan menerapkan metode geometri bestfitting L2-Norm Minimization, dengan demikian diharapkan dapat diketahui konsistensi kestabilan gerakan stasiun serta posisi-kecepatan KESR.

\section{DATA DAN METODOLOGI}

Penentuan kutub Euler dari lempeng baik dengan skala mayor, minor maupun mikro berdasarkan informasi dasar perubahan posisi titik dalam skala waktu tertentu, memiliki metode yang sama yaitu dibutuhkan minimal pergeseran/kecepatan pergerakan tiga (3) stasiun/titik yang berbeda dengan sebaran yang idealnya merata di dalam satu blok lempeng rigid dan tidak terletak pada zona transisi antar lempeng yang dipengaruhi sifat elastik. Parameter kutub Euler ditentukan menggunakan asumsi bumi berbentuk bola ideal (Gambar 2) berdasarkan persamaan sebagai berikut:

$$
V_{i}=\omega_{i} \times(X, Y, Z)_{i}
$$

Dimana $V$ adalah vektor kecepatan, $\omega$ adalah kecepatan rotasi, dan $(X, Y, Z)$ adalah koordinat geosentrik dari kutub Euler.

Algoritma geometrik digunakan di dalam penelitian ini dalam rangka mencari konsistensi hasil estimasi parameter kutub Euler adalah L2-Norm Minimization atau Least Squares yang meminimumkan jumlah kuadrat perbedaan (E) antara nilai pengamatan (L) dengan nilai hasil estimasi (X)

$$
E=\sum_{n=1}^{i}(L-X)^{2} \rightarrow \text { minimum }
$$

Algoritma di atas dilakukan secara simultan dengan menggunakan hipotesis awal residual nilai pengamatan dan nilai estimasi untuk stasiun pengamatan yang terletak di dalam satu lempeng adalah $\leq 5 \mathrm{~mm}$. Hal ini didasarkan pada kemampuan maksimum deteksi kecepatan pergerakan menggunakan teknologi geodesi satelit untuk data berdurasi lama. Nilai residual yang melebihi batas tersebut, untuk selanjutnya tidak digunakan dalam estimasi KESR dengan mengasumsikan bahwa stasiun pengamatan terletak pada zona transisi batas lempeng yang dipengaruhi deformasi elastik akibat aktifitas interaksi antar lempeng atau terletak di zona lempeng yang berbeda. Adapun kecepatan stasiun pengamatan GNSS GPS yang digunakan adalah stasiun tetap dan episodik tahun 1992-2017 yang dimiliki oleh Badan Informasi Geospasial Indonesia (Gambar 2). 


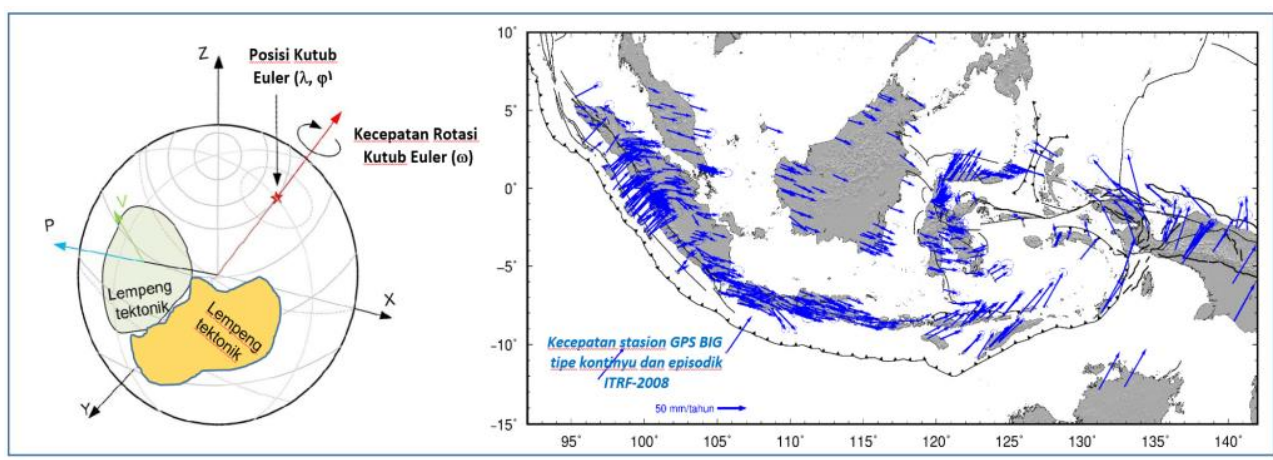

Gambar 2. Parameter kutub Euler (kiri) dan sebaran stasiun GNSS GPS BIG tipe kontinu dan episodik di dalam ITRF 2008 yang digunakan pada penelitian ini (kanan).

Tahapan pengolahan data GNSS-GPS adalah menggunakan perangkat lunak GAMIT GLOBK 10.6 dengan prosedur penentuan solusi harian, solusi bulanan dan solusi tahunan setelah mengestimasikan besarnya efek kegempaan (baik co-seismic maupun post-seismic) dengan tujuan mendapatkan solusi kecepatan pergerakan linier yang mengakomodir gerakan rigid lempeng. Untuk mendapatkan pemetaan kecepatan dalam sistem kerangka referensi global, maka dilakukan transformasi Helmert dari solusi free multi-baseline ke dalam ITRF-2008. Solusi kecepatan linier masing-masing stasiun selanjutnya digunakan sebagai input pada persamaan 1 untuk mendapatkan parameter KESR.

\section{HASIL DAN ANALISIS}

Stabilitasi estimasi KESR lempeng minor Sunda dengan metode ini menghasilkan hanya 65 stasiun pengamatan tipe kontinu dan episodik relatif stabil terletak di daerah rigid lempeng minor Sunda. Pada Tabel 1 terlihat nilai stabilisasi dari metoda L2-Norm Minimization memberikan kisaran nilai 0.13 1 yang menunjukkan kestabilan estimasi kecepatan stasiun dari hasil kalkulasi kutub Euler terhadap kecepatan hasil pengamatan. Untuk stasiun-stasiun dengan nilai stabilisasi lebih dari 1 dianggap tidak berada pada lempeng rigid minor Sunda. Dalam penghitungannya terdapat stasiun-stasiun yang terdapat di dalam zona rigid terkait tetapi memiliki nilai stabilisasi lebih dari 1 dan pengujian menunjukkan adanya deformasi lokal yang mempengaruhi stasiun tersebut sehingga tidak dimasukkan ke dalam daftar stasiun yang digunakan untuk penentuan KESR. Nilai perbedaan kecepatan masing masing stasiun dalam penentuan KESR terkecil adalah $-0.050^{\circ} /$ juta tahun di stasiun KRPN sampai dengan $0.037^{\circ} / \mathrm{juta}$ tahun di stasiun SNYP. Sedangkan perbedaan azimuth masing masing stasiun dalam penentuan KESR adalah berkisar $-7.08^{\circ}$ di stasiun NGAT dan $6.79^{\circ}$ di stasiun SAND. Secara spasial terlihat pada Gambar 3, bahwa stasiun-stasiun yang memiliki deviasi yang lebih besar dari nilai-nilai tersebut di atas baik untuk nilai stabilisasi, kecepatan dari KESR maupun dari azimuth nya, terletak di luar zona rigid lempeng mikro Sunda. Nilai residual kecepatan dalam komponen utara-selatan dan barat-timur yang selanjutnya dinyatakan menggunakan kecepatan absolut sebagaimana diuraikan pada Tabel 1 dan Gambar 3. Residual kecepatan absolut terlihat sangat kecil untuk stasiun-stasiun yang terletak di dalam blok rigid lempeng minor Sunda, sedangkan untuk daerah daerah yang diketahui secara geologi merupakan daerah diffuse yang menggambarkan perbatasan atau perubahan dari sifat satu blok rigid terhadap blok rigid lainnya menunjukkan nilai deviasi yang besar yaitu di Sumatra bagian barat, pulau Jawa bagian selatan yang memanjang ke Bali - Nusa Tenggara berbelok ke utara pada pulau Sulawesi bagian barat. 


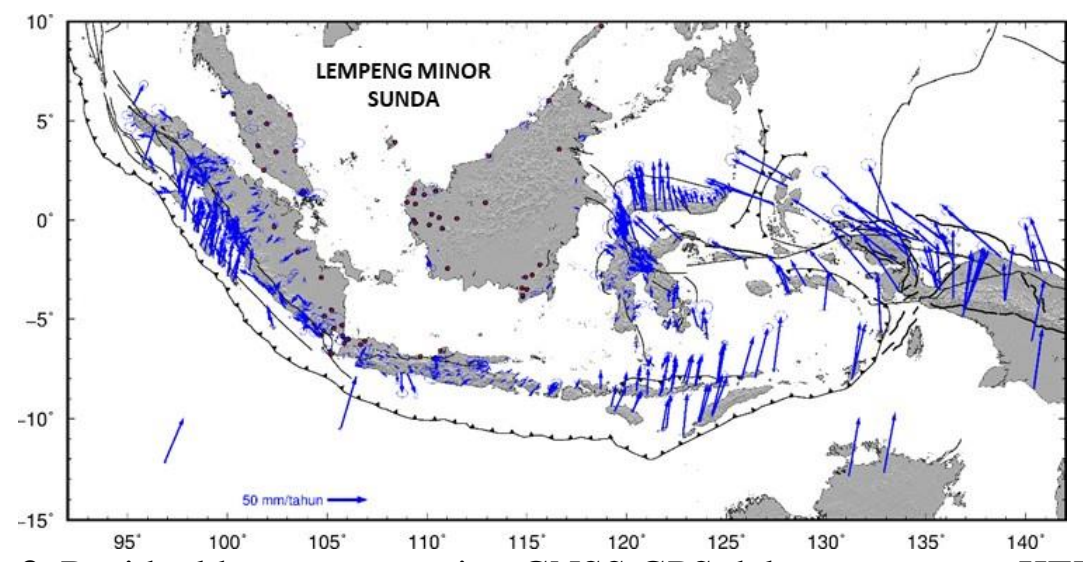

Gambar 3. Residual kecepatan stasiun GNSS GPS dalam penentuan KERS lempeng minor Sunda.

Tabel 1. Kecepatan serta azimuth hasil pengamatan serta estimasi dari nilai Kutub Euler dari masing-masing stasiun pengamatan.

\begin{tabular}{|c|c|c|c|c|c|c|c|c|c|c|}
\hline No & \begin{tabular}{|l|} 
Stasion \\
\end{tabular} & Bujur & 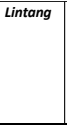 & \begin{tabular}{|l|} 
Stabilisasi \\
\end{tabular} & \begin{tabular}{|c|} 
Kecepatan \\
pengamatan \\
$\left(0.1^{\circ}\right.$ /Juta \\
tahun)
\end{tabular} & \begin{tabular}{|c|} 
Kecepatan \\
kalkulasi \\
dari Kutub \\
Euler \\
$\left(0.1^{\circ} /\right.$ Juta \\
tahun $)$ \\
\end{tabular} & $\begin{array}{c}\text { Azimuth } \\
\text { pengamatan } \\
\left({ }^{\circ}\right)\end{array}$ & \begin{tabular}{|c|} 
Azimuth \\
kalkulasi iari \\
Kutub Euler \\
$\left({ }^{\circ}\right)$
\end{tabular} & \begin{tabular}{|c|} 
Total \\
residual \\
kecepatan \\
absolut \\
$(\mathrm{mm} / \mathrm{th})$
\end{tabular} & \begin{tabular}{|c|} 
Ketelitian \\
total residual \\
kecepatan \\
absolut \\
(mm/th)
\end{tabular} \\
\hline 1 & ASIN & 114.752 & \begin{tabular}{|l|} 
\\
\end{tabular} & \begin{tabular}{l|l}
0.86 \\
\end{tabular} & 2.68 & \begin{tabular}{l|l|}
2.69 \\
\end{tabular} & \begin{tabular}{ll|}
113.22 \\
\end{tabular} & 113.11 & 0.076 & 0.252 \\
\hline 2 & RIAM & 114.994 & -3.509 & 0.64 & 2.68 & 2.69 & 112.71 & 113.26 & 0.265 & 0.420 \\
\hline 3 & TERA & 110.109 & -0.238 & 0.44 & 2.77 & 2.73 & 110.29 & 109.84 & 0.474 & 0.602 \\
\hline 4 & CNAT & 108.388 & 3.941 & 0.28 & 2.87 & 2.82 & 108.64 & 108.09 & 0.573 & 0.782 \\
\hline 5 & MATA & 111.029 & -2.45 & 0.64 & 2.69 & 2.67 & 112.06 & 110.84 & 0.600 & 0.685 \\
\hline 6 & NGAN & 115.265 & -2.776 & 0.63 & 2.71 & 2.71 & 111.87 & 113.22 & 0.636 & 0.703 \\
\hline 7 & UMAS & 110.425 & 1.468 & 0.31 & 2.75 & 2.77 & 110.97 & 109.68 & 0.686 & 0.752 \\
\hline 8 & AHAP & 110.759 & -0.426 & 0.34 & 2.69 & 2.73 & 111.71 & 110.24 & 0.772 & 0.825 \\
\hline 9 & PAGA & 110.094 & -2.243 & 0.4 & 2.59 & 2.67 & 110.58 & 110.26 & 0.802 & 0.558 \\
\hline 10 & KUAL & 103.139 & 5.319 & 0.24 & 2.81 & 2.82 & 106.57 & 104.79 & $0.870 \mid$ & 1.269 \\
\hline 11 & CGON & 106.052 & -6.021 & 0.41 & 2.57 & 2.51 & 107.23 & 108.73 & 0.909 & 0.758 \\
\hline 12 & SAMB & 109.298 & 1.365 & 0.18 & 2.84 & 2.76 & 110.04 & 109.06 & 0.937 & 1.382 \\
\hline 13 & GALL & 109.365 & 1.542 & 0.71 & 2.66 & $2.77 \mid$ & 108.73 & 109.07 & 1.051 & 0.575 \\
\hline 14 & PPPC & 118.74 & 9.773 & 0.42 & 3.13 & 3.02 & 113.04 & 112.63 & 1.101 & 0.829 \\
\hline 15 & BAKA & 105.752 & -5.863 & 0.23 & 2.56 & 2.51 & 106.29 & 108.5 & 1.110 & 1.205 \\
\hline 16 & CPUT & 112.923 & 0.877 & 0.82 & 2.86 & 2.78 & 112.9 & 111.16 & 1.113 & 1.094 \\
\hline 17 & PALE & 104.7 & -2.902 & 0.68 & 2.49 & 2.6 & 106.16 & 107.16 & 1.122 & 0.805 \\
\hline 18 & 2590 & 110.409 & -6.984 & 0.15 & 2.64 & 2.53 & 111.94 & 111.65 & 1.136 & 1.529 \\
\hline 19 & SMUR & $105.777 \mid$ & -5.828 & 0.23 & 2.39 & 2.51 & 108.71 & 108.51 & 1.230 & 1.018 \\
\hline 20 & CPKL & 109.669 & -6.887 & 0.46 & 2.64 & 2.53 & 112.07 & 111.18 & 1.256 & 0.942 \\
\hline 21 & HARI & 114.784 & -3.802 & 0.41 & 2.8 & 2.68 & 114.26 & 113.22 & 1.273 & 1.070 \\
\hline 22 & HALU & 115.656 & $-2.261 \mid$ & 0.87 & $2.6 \mid$ & 2.73 & 112.85 & 113.29 & 1.365 & 0.762 \\
\hline 23 & BPJG & 105.321 & -5.47 & 0.28 & 2.6 & 2.52 & 105.39 & 108.13 & 1.461 & 1.336 \\
\hline 24 & soso & 110.231 & 0.292 & 0.43 & 2.62 & 2.74 & 111.76 & 109.8 & 1.487 & 0.659 \\
\hline 25 & NGAU & 110.6 & 0.122 & 0.31 & 2.68 & 2.74 & 113.15 & 110.04 & 1.598 & 1.322 \\
\hline 26 & GRIK & 101.13 & 5.439 & 0.25 & 2.64 & 2.81 & 104.17 & 103.55 & 1.663 & 0.816 \\
\hline 27 & CPSR & 105.834 & -6.226 & 0.67 & 2.37 & 2.5 & 106.02 & 108.65 & 1.701 & 1.485 \\
\hline 28 & |UMSS & 116.112 & 6.039 & 0.27 & 2.81 & 2.93 & 109.52 & 111.88 & 1.704[ & 1.784 \\
\hline 29 & BTU1 & 109.322 & 0.001 & 0.37 & 2.56 & 2.73 & 108.58 & 109.34 & 1.713 & 1.048 \\
\hline 30 & SELU & 109.854 & 1.283 & 0.38 & 2.63 & 2.76 & 111.85 & 109.39 & 1.809 & 0.827 \\
\hline 31 & CNAU & 116.621 & 3.586 & 1 & 2.71 & 2.88 & 113.78 & 112.56 & 1.825 & 0.191 \\
\hline 32 & BATU & 114.791 & -3.867 & 0.39 & 2.84 & 2.68 & 111.31 & 113.24 & 1.847 & 0.604 \\
\hline 33 & PEKN & 103.39 & 3.493 & 0.23 & 2.9 & 2.77 & 102.39 & 105.21 & 1.920 & 1.229 \\
\hline 34 & TLOH & 102.419 & 3.45 & 0.24 & 2.95 & 2.76 & 103.72 & 104.61 & 1.920 & 0.800 \\
\hline 35 & BSMG & 110.425 & -6.947 & 0.13 & 2.63 & 2.53 & 115.38 & 111.65 & 1.929 & 2.133 \\
\hline 36 & SINT & 111.49 & 0.082 & 0.52 & 2.56 & 2.75 & 111.88 & 110.55 & 1.942 & 0.420 \\
\hline 37 & KAYA & 109.411 & 0.812 & 0.42 & 2.58 & 2.75 & 111.17| & 109.23 & 1.946 & 0.568 \\
\hline 38 & CPON & 109.329 & -0.004 & 0.47 & 2.62 & 2.73 & 112.95 & 109.35 & 1.998 & 1.284 \\
\hline 39 & BEHR & 101.517 & 3.765 & 0.27 & 2.95 & 2.76 & 105.75 & 104.01 & 2.029 & 1.540 \\
\hline 40 & CJKT & 106.885 & -6.11 & 0.57 & 2.67 & 2.52 & 106.26 & 109.28 & 2.055 & 0.926 \\
\hline 41 & BBTN & 105.953 & -6.018 & 0.3 & 2.41 & 2.51 & 104.5 & 108.67 & 2.062 & 2.171 \\
\hline 42 & PONT & 109.41 & -0.146 & 0.61 & 2.52 & 2.72 & 110.78 & 109.42 & 2.082 & 0.364 \\
\hline 43 & SARI & 114.936 & -2.882 & 0.55 & 2.5 & 2.71 & 111.03 & 113.07 & 2.235 & 1.666 \\
\hline 44 & MENG & 105.221 & -4.553 & 0.33 & 2.34 & 2.55 & 105.66 & 107.85 & \begin{tabular}{l|l} 
& \\
2.290
\end{tabular} & 1.639 \\
\hline 45 & BAWO & 105.743 & -5.311 & 0.4 & 2.74 & 2.53 & 110.17 & 108.36 & 2.291 & 1.585 \\
\hline 46 & SKWG & 109.001 & 0.907 & 0.4 & 2.52 & 2.75 & 109.97 & 108.98 & 2.324 & 0.624 \\
\hline 47 & CBAS & 109.301 & 1.361 & 0.4 & 2.96 & 2.76 & 106.68 & 109.06 & 2.356 & 0.811 \\
\hline 48 & SING & 103.773 & 1.362 & 0.42 & 2.94 & 2.71 & 104.14 & 105.78 & 2.417 & 0.479 \\
\hline 49 & CUJK & 105.213 & -6.747 & 0.76 & 2.43 & 2.48 & 102.74 & 108.38 & 2.457 & 2.468 \\
\hline 50 & CIPR & 110.667 & -6.596 & 0.24 & 2.79 & 2.55 & 110.11 & 111.69 & 2.516 & 0.808 \\
\hline 51 & USMP & 100.304 & 5.358 & 0.18 & 2.56 & 2.8 & 101.51 & 103.04 & 2.524 & 1.704 \\
\hline 52 & JMBI & 103.52 & -1.616 & 0.78 & 2.46 & 2.63 & 110.64 & 106.16 & 2.572 & 1.404 \\
\hline 53 & SSEK & 103.814 & 1.47 & 0.36 & 3 & 2.72 & 107.02 & 105.79 & 2.856 & 1.497 \\
\hline 54 & CSEM & 110.377 & -6.987 & 0.57 & 2.8 & 2.53 & 114.61 & 111.63 & 3.066 & 2.370 \\
\hline 55 & GETI & 102.106 & 6.226 & 0.16 & 3.15 & 2.83 & 104.07 & 104.05 & 3.231 & 1.595 \\
\hline 56 & BIN1 & 113.094 & 3.24 & 0.33 & 2.53 & 2.84 & 109.01 & 110.8 & 3.268 & 1.973 \\
\hline 57 & CTGR & 106.664 & -6.291 & 0.72 & 2.82 & 2.51 & 106.82 & 109.19 & 3.321 & 0.310 \\
\hline 58 & SNYP & 103.849 & 1.379 & 0.29 & 3.09 & 2.72 & 106.51 & 105.82 & 3.762 & 1.552 \\
\hline 59 & SAND & 118.121 & 5.842 & 0.27 & 3.09 & 2.94 & 119.7 & 112.91 & 3.842 & 3.903 \\
\hline 60 & Ктвм & 104.86 & -4.847 & 0.36 & 2.21 & 2.54 & 112.66 & 107.69 & 3.891 & 0.998 \\
\hline 61 & GMUS & 101.964 & 4.863 & 0.26 & 3.13 & 2.8 & 100.16 & 104.14 & 3.959 & 1.424 \\
\hline 62 & PDIC & 101.811 & 2.526 & 0.28 & 2.94 & 2.73 & 97.36 & 104.37 & 4.044 & 3.086 \\
\hline 63 & NGAT & 102.334 & -0.349 & 0.23 & 2.92 & 2.65 & 98.09 & 105.17 & 4.355 & 2.979 \\
\hline 64 & NTUS & 103.68 & 1.346 & 0.73 & 3.0 & 2.71 & 98.64 & 105.72 & 4.874 & 2.7 \\
\hline 65 & KRPN & 104.811 & -5.598 & 0.29 & $\begin{array}{c}1.98 \\
\end{array}$ & 2.51 & 105.72 & 107.84 & 5.399 & 2.484 \\
\hline
\end{tabular}




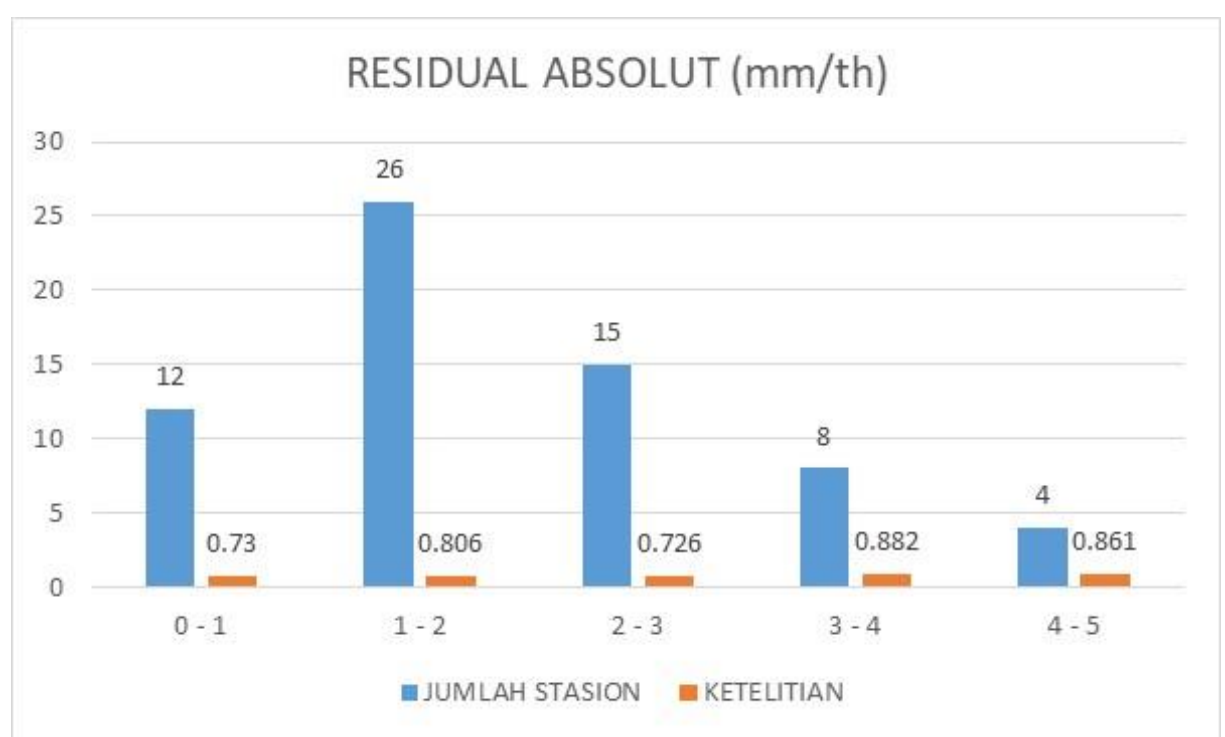

Gambar 4. Histogram residual kecepatan stasiun GNSS GPS dalam penentuan KERS lempeng minor Sunda.

Sebaran nilai residual absolut terlihat pada histogram di Gambar 4, yang hampir memenuhi sebaran normal. Pada selang residual absolut $0-1 \mathrm{~mm} / \mathrm{th}$ ketelitian \pm 0.730 $\mathrm{mm} /$ th terdapat 12 stasiun, selang $1-2 \mathrm{~mm} / \mathrm{th}$ ketelitian $\pm 0.806 \mathrm{~mm} /$ th terdapat 26 stasiun, selang $2-3 \mathrm{~mm} /$ th ketelitian $\pm 0.726 \mathrm{~mm} / \mathrm{th}$ terdapat 15 stasiun, selang 3-4 $\mathrm{mm} / \mathrm{th}$ ketelitian $\pm 0.806 \mathrm{~mm} /$ th terdapat 8 stasiun dan selang 4-5mm/th ketelitian $\pm 0.806 \mathrm{~mm} / \mathrm{th}$ terdapat 4 stasiun. Bias histogram pada selang
0-1 $\mathrm{mm} /$ th disebabkan oleh durasi waktu pemantauan yang pendek untuk stasiun kontinu (misal CNAT dan CGON) serta frekuensi pemantauan yang masih sedikit untuk data episodik (misalnya ASIN dan RIAM). Secara keseluruhan nilai residual absolut menunjukkan tingkat keakurasian yang tinggi dalam penentuan KESR dengan menggunakan metoda L2-Norm Minimization ini yaitu di bawah $5 \mathrm{~mm} /$ th dengan ketelitian mendekati $1 \mathrm{~mm} / \mathrm{thn}$.

Tabel 2. Perbandingan parameter KESR Lempeng Minor Sunda terhadap parameter model-model penelitian sebelumnya.

\begin{tabular}{|c|c|c|c|c|c|}
\hline \multirow[t]{2}{*}{ Pustaka } & \multirow[t]{2}{*}{ Kerangka Referensi } & \multirow{2}{*}{$\begin{array}{c}\text { Jumlah } \\
\text { Stasion } \\
\text { Pengamatan }\end{array}$} & \multicolumn{3}{|c|}{ Parameter Kutub Euler Sesaat Resen } \\
\hline & & & Lintang $(\theta)$ & Bujur $(\theta)$ & $\begin{array}{c}\text { Kecepatan } \\
\text { rotasi } \\
\text { (\%/juta tahun) }\end{array}$ \\
\hline Sella dkk (2002) & REVEL & 2 & 38.86 & -86.94 & $0.393 \pm 0.062$ \\
\hline Kreemer dkk (2003) & NNR-GSRM1.2 & 9 & 47.3 & -90.13 & $0.392 \pm 0.008$ \\
\hline Bock dkk (2003) & ITRF2000 & 16 & 49.8 & -95.9 & $0.320 \pm 0.010$ \\
\hline Prawirodirdjo dkk (2004) & ITRF2000 & 2 & 32.6 & -86.8 & $0.462 \pm 0.064$ \\
\hline Kreemer dkk (2006) & ITRF2000 & 21 & 43.6 & -89.6 & $0.366 \pm 0.013$ \\
\hline Simons dkk (2007) & ITRF2000 & 28 & 49.0 & -94.2 & $0.336 \pm 0.007$ \\
\hline DeMets dkk (2010) & ITRF2000 & 18 & 48.5 & -93.9 & 0.326 \\
\hline Argus dkk (2011) & NNR-MORVEL56 & - & 50.1 & -95.1 & $0.337 \pm 0.020$ \\
\hline Altamimi dkk (2012) & ITRF2008 & 2 & $44.2 \pm 1.5$ & $-87.3 \pm 0.5$ & $0.388 \pm 0.308$ \\
\hline Kreemer dkk (2014) & NNR-GSRM2.1 & 11 & 51.11 & -91.75 & 0.350 \\
\hline Mustafar dkk (2017) & IGS08 (ITRF2008) & 14 & $48.05 \pm 1.1$ & $-88.51 \pm 0.4$ & $0.241 \pm 0.015$ \\
\hline Yong dkk (2017) & ITRF2008 & 10 & 44.16 & -87.22 & $0.349 \pm 0.038$ \\
\hline Susilo (2018) & IGS08 (ITRF2008) & 65 & 51.991 & -96.495 & $0.291 \pm 0.0023$ \\
\hline Penelitian ini & IGS08 (ITRF2008) & 65 & 53.721 & -99.247 & $0.287 \pm 0.0013$ \\
\hline
\end{tabular}


Parameter KESR yang diperoleh pada penelitian ini adalah (53.721 LU, 99.247 BB, $0.287 \pm 0.0013^{\circ} / \mathrm{juta}$ tahun). Perbandingan para-meter KESR lempeng minor Sunda dari penelitian ini terhadap penelitian-penelitian sebelumnya terlihat pada Tabel 1. Secara umum deviasi posisi dan kecepatan KESR di dalam penelitian ini masih dalam keselarasan dengan model-model yang diperoleh secara geologi (REVEL, NNR-GSRM, NNRMORVEL) dan secara geodetik (ITRF, IGS08). Perbedaan muncul disebabkan oleh pola sebaran stasiun beserta jumlahnya, serta panjang durasi pengamatan yang berbeda. Stasiun-stasiun yang tidak memenuhi kendala maksimum merupakan stasiun-stasiun yang diperkirakan tidak terletak di daerah rigid lempeng minor atau mengalami deformasi lokal yang mengakibatkan memiliki residual absolut lebih besar dari $5 \mathrm{~mm} / \mathrm{th}$.

\section{PENUTUP}

Estimasi KESR secara geometrik menggunakan data geodetik kecepatan pergerakan stasiun GNSS-GPS menunjukkan kontribusi geodesi modern dalam mempelajari dan memahami pola tektonik di Indonesia. Nilai estimasi resen yang dihasilkan berada dalam keselarasan dengan model estimasi secara geologi yang bersifat jangka panjang (jutaan tahun). Diharapkan pada masa mendatang, dengan semakin banyak jumlah serta meratanya sebaran stasiun pemantau, maka kendala penentuan parameter KESR secara geometrik akan semakin ketat dan keakurasian semakin meningkat. Hal lain yang perlu diperhatikan juga pada epok mendatang adalah terdapat kemungkinan kemunculan Stages Euler Pole (SEP) di zona triple junction yang terletak di wilayah Indonesia bagian Timur-Laut, dengan demikian penghitungan deformasi sekular menggunakan data Kutub Euler Sesaat Resen (KESR) harus mempertimbangkan model deformasi elastik di zona perbatasan antar lempeng untuk mengakomodir kemungkinan perubahan arah atau pengurangan kecepatan gerakan. Sedangkan untuk stasiun-stasiun pengamatan yang tidak diikutsertakan dalam estimasi KESR, pada tahap selanjutnya dipelajari menggunakan algoritma dilatasi (regangan geser) dan algoritma deformasi elastik untuk mengetahui status deformasi dari zona terkait, yaitu sebagai daerah transisi di dekat batas lempeng atau terletak pada lempeng mayor/minor/mikro yang berbeda.

\section{REFERENSI}

Altamimi, Z., Métivier, L., Collilieux, X., (2012), ITRF2008 plate motion model. J. Geophys.Res. Solid Earth 117(B7), B07402, doi: 10.1029/2011JB008930.

Becker, J. J., Sandwell, D. T., Smith, W. H. F., Braud, J., Binder, B. Depner, J., Fabre, D., Factor, J., Ingalls, S., Kim, S. H. dan Ladner, R. (2009) : Global bathymetry and elevation data at 30 arc seconds resolution: SRTM30_PLUS, Marine Geodesy, 32(4), $355-371$

Bock, Y., Prawirodirdjo, L., Genrich, J. F., Stevens, C. W.,McCaffrey, R., Subarya, C., Puntodewo, S. S. O., Calais, E., (2003), Crustal motion in Indonesia from Global Positioning System measurements. J. Geophys. Res. Solid Earth 108(B8), 2367, doi: 10.1029/2001JB000324.

Cox, A., and Hart, R.B., (1986), Plate tectonics: How it works, Blackwell, p.63-84

DeMets C, Gordon RG, Argus DF., (2010), Geologically current plate motions.Geophys J Int 181:1-80. doi:10.1111/j.1365-246X.2009. 04491. $\mathrm{x}$

Hamilton, W., (1979): Tectonics of the Indonesian region, U.S. Geol. Surv. Prof. Pap. 1078, Boulder, Colo

Kreemer, C., Holt, W. E., Haines, A. J., (2003), An integrated global model of present-day plate motions and plate boundary deformation. Geophys. J. Int 154(1), 8-34, doi:10.1046/j.1365246X.2003.01917.x.

Kreemer C, Lavallée Da, Blewitt G, Holt WE (2006), On the stability of a geodetic no-net-rotation frame and its implication for the International Terrestrial Reference Frame. Geophys 
Res

Lett

$33: 1-5$ doi:10.1029/2006GL027058

Kreemer, C., Blewitt, G., Klein, E. C., (2014), A geodetic plate motion and Global Strain Rate Model. Geochem. Geophys. Geosyst.15 (10), 3849-3889, doi: 10.1002/2014GC005407.

Mustafar, M.A., W.J.F. Simons, F. Tongkul, C. Satirapod, K.M. Omar, P.N.A.M.Visser., (2017), Quantifying deformation in North Borneo with GPS, J Geod 91:1241-1259, doi: 10.1007/s00190-017-1024-Z

Prawirodirdjo, L., Bock, Y., (2004), Instantaneous global plate motion model from 12 years of continuous GPS observations.J. Geophys. Res. Solid Earth 109(B8), B08405, doi: 10.1029/2003JB002944.

Sella, G. F., Dixon, T. H., Mao, A., (2002), REVEL: A model for Recent plate velocities from space geodesy. $J$.
Geophys. Res. Solid Earth 107(B4),

ETG 11-1-ETG 11-30, doi: 10.1029/2000JB000033.

Simons WJF, Socquet A, Vigny C, Ambrosius BAC, Haji Abu S, Promthong C, Subarya C, Sarsito DA, Matheussen S, Morgan P, SpakmanW(2007) A decade of GPS in Southeast Asia: resolving Sundaland motion and boundaries. $J$ Geophys Res 112:B06420. doi: 10.1029/2005JB003868

Susilo, S., (2018), Realisasi Model Deformasi Geodetik Untuk Model Semidinamik Datum Indonesia di Indonesia, Disertasi Program Doktor -Prodi Teknik Geodesi dan Geomatika - ITB Yong, C.Z., P.H. Denys, C.F. Pearson. (2017), Present-day kinematics of the Sundaland plate, Journal of Applied Geodesy, Volume 11, Issue 3, pp.169177. Doi: 10.1515/jag-2016-0024 